\title{
Mobile Learning sebagai Fasilitas Belajar Mandiri Pembelajaran Senam Lantai pada Mahasiswa Jurusan Ilmu Keolahragaan
}

\author{
Sapto Adi ${ }^{1}$, Abi Fajar Fathoni ${ }^{1}$ \\ ${ }^{1}$ Fakultas Ilmu Keolahragaan-Unversitas Negeri Malang
}

\begin{tabular}{l}
\hline INFO ARTIKEL \\
\hline Riwayat Artikel: \\
Diterima: 10-06-2020 \\
Disetujui: 26-08-2020 \\
\hline
\end{tabular}

\section{Kata kunci:}

mobile learning; independent learning; gymnastics; mobile learning;

belajar mandiri; senam lantai

\begin{abstract}
Gymnastics is a sport that requires a high mental for people who will do floor gymnastics skills movements. Mental can be improved if the person is very good in perception and knowledge about gymnastics skills. The purpose of this study is to provide independent learning facility for students to learn gymnastics skills. The method used is product development in the form of supporting software for mobile learning and testing for students. The result obtained was the students could learn gymnastic skills without any place and time restrictions so that the perception of gymnastics skills could be enriched independently. The conclusion of this research was that mobile learning helped to improve students' perception and knowledge of gymnastic skills without being limited to time and place of lecture.
\end{abstract}

ABSTRAK

\begin{abstract}
Abstrak: Senam lantai merupakan olahraga yang memerlukan mental tinggi bagi orang yang akan melakukan gerakan keterampilan senam lantai. Mental dapat ditingkatkan jika orang tersebut kaya dengan wawasan dan pengetahuan tentang keterampilan senam lantai. Tujuan penelitian ini adalah untuk memberikan fasilitas belajar mandiri mahasiswa dalam belajar keterampilan senam lantai. Metode yang digunakan adalah pengembangan produk berupa software penunjang mobile learning dan uji coba kepada mahasiswa. Hasil yang diperoleh yakni mahasiswa dapat mempelajari keterampilan senam tanpa ada batasan tempat dan waktu sehingga wawasan keterampilan senam lantai bisa diperkaya secara mandiri. Kesimpulan dari penelitian ini mobile learning membantu meningkatkan wawasan dan pengetahuan mahasiswa terhadap keterampilan senam lantai tanpa dibatasi waktu perkuliahan dan tempat kuliah.
\end{abstract}

\author{
Alamat Korespondensi: \\ Sapto Adi \\ Fakultas Ilmu Keolahragaan \\ Unversitas Negeri Malang \\ Jalan Semarang 5 Malang \\ E-mail: Sapto.adi.fik@um.ac.id
}

Senam lantai adalah salah satu jenis senam artistik yang memadukan berbagai bentuk keterampilan tubuh yang menonjolkan keindahan gerak, kerumitan gerak, kekuatan gerak, keluwesan gerak, keseimbangan, dan kelenturan gerak untuk dipertunjukkan dalam lapangan senam lantai (Nassar, 2017). Seorang atlet senam lantai bebas meramu berbagai macam gerak tubuh seperti meroda, melenting, roll, jatuhan, salto, dan lain sebagainya dengan berbagai gaya dan ekspresi (Sands et al., 2016). Dengan kata lain, gerakan dalam senam lantai dapat dibilang tak terbatas (unlimited exploration) sejauh atlet melakukan performanya tanpa bantuan alat (Issn, 2011). Oleh karena itu, atlet senam lantai harus banyak melatih tubuhnya dengan berbagai jenis latihan tubuh dari berbagai disiplin, seperti tari balet, tari jalanan (dance street), dan gerakan-gerakan akrobat (Mayer, 2010).

Sesuai perkembangan zaman, senam lantai merupakan matakuliah di Perguruan Tinggi bidang keolahragaan (Wallhead \& Ntoumanis, 2016). Tujuan dari matakuliah senam lantai adalah untuk menganalisis secara ilmiah mengenai keterampilan dan kemampuan olahraga senam lantai, mencetak para pelatih, ilmuan dan praktisi dalam bidang olahraga senam lantai, membekali mahasiswa dengan keterampilan hingga keilmuan di bidang olahraga senam lantai (Department for Culture Media and Sport, 2015). Agar tujuan pelaksanaan matakuliah senam lantai dapat tercapai, mahasiswa harus mengetahui, mempelajari, dan melakukan beberapa keterampilan senam lantai (Spriet, 2014). Dengan melakukan dan mengalami sendiri maka akan muncul beberapa permasalahan saat belajar senam lantai yang harus dipecahkan dan dicari solusinya (Laursen, 2010). Dengan pengalaman yang ada diharapkan memperkaya keahlian mahasiswa (Maruhashi, Kihara, \& Higashi, 2017). Apabila ketika nanti menjadi ilmuan, pelatih atau praktisi di bidang olahraga senam lantai dapat digunakan untuk mengatur manajemen profesi dan mencapai tujuan yang ingin dihasilkan (Holloszy \& Coyle, 2017). 
Penguasaan keterampilan senam lantai dalam proses latihannya perlu mental yang kuat (Sheth, 2016). Dengan mental yang kuat, maka pikiran dan gerak otot mahasiswa dapat mempraktikkan gerakan senam lantai yang tergolong sangat rumit (McKenzie et al., 2014). Apalagi pengaruh dari pengalaman teman yang gagal saat mempraktikkan keterampilan senam lantai dan bahkan menyebabkan cedera, akan memengaruhi tingkat mental mahasiswa yang ingin berlatih senam lantai (Allen, 2016). Oleh sebab itu, pada matakuliah senam lantai di jurusan Ilmu Keolahragaan ini perlu ada penguatan mental mahasiswa di dalam perkuliahan (Eagleman, 2013). Mental seseorang dapat menjadi kuat ketika memiliki pengetahuan lebih tentang sesuatu yang memerlukan mental tersebut (Gregersen, 2014). Dengan kata lain, mental mahasiswa dapat kuat jika mahasiswa memiliki banyak pengetahuan mengenai gerakan senam lantai (Ric, 2015). Dalam hal ini mengarah pada proses belajar kognitif yaitu proses penyampaian informasi senam lantai dari dosen kepada mahasiswa (Ji \& Yap, 2016). Dalam proses transfer informasi tersebut, juga diberikan penguatan dengan memberikan motivasi secara verbal kepada mahasiswa (Pelletier, Rocchi, Vallerand, Deci, \& Ryan, 2013).

Namun, terdapat permasalahan dalam proses belajar kognitif tersebut. Salah satu permasalahan tersebut adalah terbatasnya waktu perkuliahan. Jika dosen melakukan penyampaian informasi yang luas dan pemberian motivasi kepada mahasiswa maka akan memerlukan banyak waktu. Belum lagi setiap mahasiswa memiliki tingkat dan karakteristik mental yang berbeda (Hasibuan, Syah, \& Marzuki, 2018). Dengan demikian, perlakuan dosen untuk memberikan motivasi penguatan mental akan berbeda untuk setiap mahasiswa (Proctor et al., 2011). Jika pertemuan perkuliahan menghabiskan banyak waktu untuk menyampaikan informasi dan pengetahuan serta pemberian motivasi penguatan mental, maka pembelajaran dalam pertemuan tersebut akan menjadi tidak efektif dan efisien (Johannessen \& Johannessen, 2018). Oleh karena itu, perlu tambahan waktu belajar mahasiswa untuk menggali pengetahuan dan motivasi diri tanpa perlu pendampingan dari dosen. Peneliti berniat untuk mengembangkan mobile learning untuk memecahkan permasalahan tersebut. Mobile learning adalah pembelajaran yang dapat dilaksanakan oleh mahasiswa dimana saja dan kapan saja waktunya tanpa harus didampingi oleh dosen. Mobile learning juga memungkinkan mahasiswa melakukan pembelajaran dengan mengakses semua materi pembelajaran sesuai kebutuhannya (Jones \& Dexter, 2014). Jika memang merasa belum cukup, mahasiswa menambah waktu belajarnya sendiri.

Dengan adanya mobile learning maka pengetahuan dan materi terkait senam lantai dapat dipelajari oleh mahasiswa di luar waktu pertemuan perkuliahan (Sharples \& Pea, 2014). Jadi, ketika pertemuan perkuliahan berlangsung, dosen tidak perlu menjelaskan tentang informasi pengetahuan tentang senam lantai, namun hanya memberikan informasi umum terkait keterampilan yang akan dilatih dan mengarahkan mahasiswa jika terdapat kesalahan saat memahami materi yang terdapat pada media pembelajaran mobile learning (Sung, Chang, \& Liu, 2016). Dengan seperti itu, saat perkuliahan berlangsung dapat digunakan untuk memaksimalkan latihan. Untuk berlatih keterampilan jasmani perlu banyak latihan dan melakukan praktik keterampilan yang sedang dilatih (Kelly, Gregson, Reilly, \& Drust, 2013).

Jika mobile learning tersebut dilaksanakan oleh dosen maka dosen akan mengembangkan bahan ajar dengan menggunakan media yang mendukung mobile learning (Gikas \& Grant, 2013). Materi yang dikemas tersebut mencakup semua materi tentang senam lantai, meliputi penjelasan detail, video, dan materi-materi yang luas yang mampu memotivasi mahasiswa dan meningkatkan mentalnya dalam mempraktikkan keterampilan senam lantai. Tentu hal tersebut seperti tujuan awal yang ingin dicapai dalam penelitian ini.

\section{METODE}

Metode yang digunakan dalam penelitian ini yaitu metode survei untuk melihat kebutuhan dan karakteristik mahasiswa yang dapat menunjang dikembangkannya mobile leaarning. Setelah diketahui karakteristik dan kebutuhan mahasiswa maka peneliti mengembangkan media pembelajaran untuk mendukung mobile learning. Media tersebut adalah software dan buku elektronik yang dapat diakses oleh mahasiswa dimana saja dan kapan saja waktunya. Sesuai dengan hasil survei, media pembelajaran mobile learning dalam bentuk software berbasis android yang didalamnya memuat konten materi tentang senam lantai, video senam lantai, alat evaluasi pengetahuan, dan software tersebut memfasilitasi mahasiswa untuk pembuatan akun sehingga mudah mengakses software tersebut. Setelah media tercipta, tahap selanjutnya yaitu dilakukan uji coba. Uji coba dilakukan pada mahasiswa jurusan Ilmu Keolahragaan Universitas Negeri Malang.

\section{HASIL}

\section{Data Hasil Analisis Kebutuhan}

Sebelum melakukan pengembangan mobile learning, peneliti melakukan survei terkait analisis kebutuhan kepada mahasiswa jurusan Ilmu Keolahragaan Universitas Negeri Malang. Hasil data analisis kebutuhan yaitu sebagai berikut. Pertama, terkait usia mahasiswa yang mengikuti perkuliahan senam lantai. Sebanyak 25,4\% mahasiswa berusia 18 tahun, sebanyak 57,6\% mahasiswa berusia 19 tahun, sebanyak 13,6\% mahasiswa berusia 20 tahun, sebanyak 1,7\% mahasiswa berusia 21 tahun, dan sebanyak $1,7 \%$ mahasiswa berusia 22 tahun. 
Kedua, memaparkan data terkait status mahasiswa. Sebanyak 18,6\% mahasiswa memiliki dua kegiatan, yaitu kuliah dan bekerja. Sebanyak $83,1 \%$ mahasiswa hanya kuliah. Ketiga, data penggunaan samrtphone, semua mahasiswa sebanyak $100 \%$ menggunakan smartphone setiap hari.

Kemudian data terkait penggunaan smartphone dalam sehari oleh mahasiswa adalah sebagai berikut. Sebanyak $8,5 \%$ mahasiswa menggunakan smartphone sebanyak 30\% dalam sehari. Sebanyak 11,9\% mahasiswa menggunakan smartphone sebanyak $40 \%$ dalam sehari. Sebanyak 23,7\% mahasiswa menggunakan smartphone sebanyak 50\% dalam sehari. Sebanyak $11,9 \%$ mahasiswa menggunakan smartphone sebanyak 60\% dalam sehari. Sebanyak 20,3\% mahasiswa menggunakan smartphone sebanyak 70\% dalam sehari. Sebanyak 20,3\% mahasiswa menggunakan smartphone sebanyak $80 \%$ dalam sehari. Sebanyak 3,4\% mahasiswa menggunakan smartphone sebanyak $90 \%$ dalam sehari.

Peneliti juga mengambil data terkait popularitas mobile learning. Adapun hasil dari data popularitas mobile learning, yakni (1) $28,8 \%$ mahasiswa mengungkapkan bahwa baru mendengar tentang mobile learning, (2) $27,1 \%$ mahasiswa mengungkapkan bahwa belum mendengar tentang mobile learning, (3) 44,1\% mahasiswa mengungkapkan bahwa sudah mendengar tentang mobile learning. Semua data di atas ditunjukkan pada tabel 1.

Tabel 1. Data Tentang Kebutuhan dan Karakteristik Kondisi Mehasiswa

\begin{tabular}{|c|c|c|c|}
\hline No. & 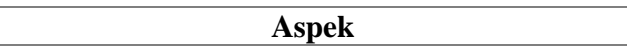 & Kategori & Persentase \\
\hline \multirow[t]{5}{*}{1.} & Usia Mahasiswa & 18 tahun & $25,4 \%$ \\
\hline & & 19 tahun & $57,6 \%$ \\
\hline & & 20 tahun & $13,6 \%$ \\
\hline & & 21 tahun & $1,7 \%$ \\
\hline & & 22 tahun & $1,7 \%$ \\
\hline \multirow[t]{2}{*}{2.} & Status mahasiswa & Kuliah dan bekerja & $18,6 \%$ \\
\hline & & Kuliah saja & $83,1 \%$ \\
\hline 3 & Penggunaan Smartphone & Semua mahasiswa menggunakan smartphone & $100 \%$ \\
\hline \multirow[t]{7}{*}{4} & Persentase penggunaan smartphone dalam sehari & $30 \%$ sehari & $8,5 \%$ \\
\hline & & $40 \%$ sehari & $11,9 \%$ \\
\hline & & $50 \%$ sehari & $23,7 \%$ \\
\hline & & $60 \%$ sehari & $11,9 \%$ \\
\hline & & $70 \%$ sehari & $20,3 \%$ \\
\hline & & $80 \%$ sehari & $20,3 \%$ \\
\hline & & $90 \%$ sehari & $3,4 \%$ \\
\hline \multirow[t]{3}{*}{5.} & Popularitas mobile learning & Baru mendengar & $28,8 \%$ \\
\hline & & Belum dengar & $27,1 \%$ \\
\hline & & Sudah mendengar & $44,1 \%$ \\
\hline
\end{tabular}

Dalam pengembangan mobile learning, data dari mahasiswa juga diambil. Hal ini dilakukan untuk mengetahui tingkat kebutuhan mobile learning dalam menunjang pembelajaran matakuliah senam lantai jurusan Ilmu Keolahragaan. Adapun hasilnya adalah sebagai berikut. Pertama, 3,4\% mahasiswa tidak setuju dikembangkan mobile learning untuk menunjang pembelajaran mata kuliah senam lantai. Kedua, 52,5\% mahasiswa setuju dikembangkan mobile learning untuk menunjang pembelajaran mata kuliah senam lantai. Ketiga, 44,1\% mahasiswa sangat setuju dikembangkan mobile learning untuk menunjang pembelajaran matakuliah senam lantai. Data tersebut ditampilkan pada grafik gambar 1 .

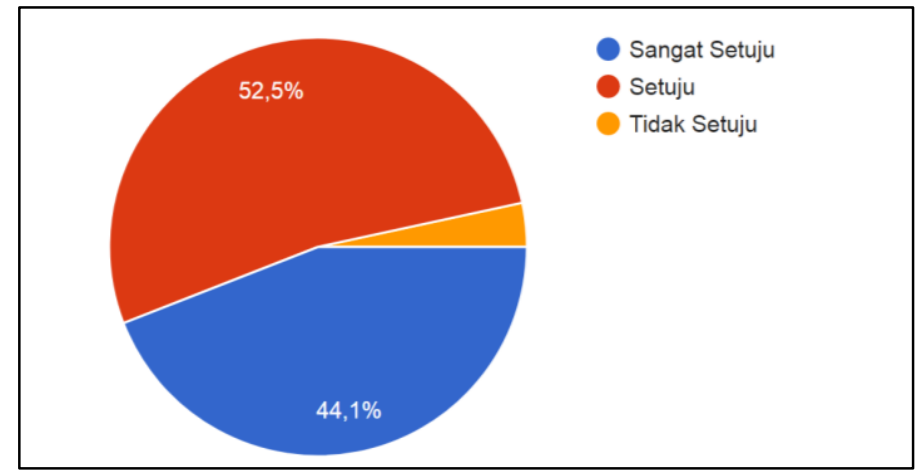

Gambar 1. Grafik Persentase Persetujuan Mahasiswa untuk Pengembangan Mobile Learning 


\section{Data Hasil Uji Coba}

Data terkait mobile learning senam lantai dapat membantu mahasiswa agar dapat mempelajari senam lantai dimana saja adalah sebagai berikut. $29,4 \%$ mahasiswa menyatakan bahwa mobile learning senam lantai sangat membantu belajar senam lantai dimana saja mereka berada. 64,7\% mahasiswa menyatakan bahwa mobile learning senam lantai membantu belajar senam lantai dimana saja mereka berada. 5,9\% mahasiswa menyatakan bahwa mobile learning senam lantai cukup membantu belajar senam lantai dimana saja mereka berada. Data tersebut divisualisasikan dalam bentuk diagram pada Gambar 2.

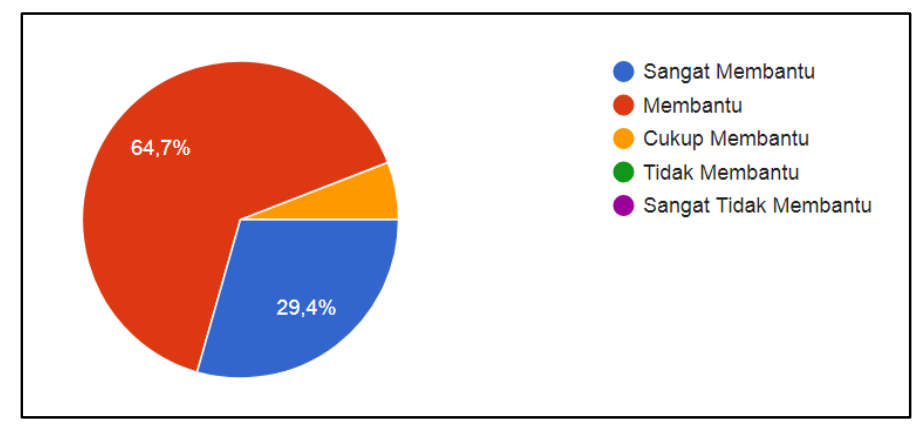

\section{Gambar 2. Diagram Persentase Mobile Learning Senam Lantai}

Data terkait mobile learning senam lantai dapat membantu mahasiswa belajar senam lantai kapan saja. Pertama, 35,3\% mahasiswa menyatakan bahwa mobile learning senam lantai sangat membantu belajar senam lantai kapan saja waktu mereka ingin belajar. Kedua, 64,7\% mahasiswa menyatakan bahwa mobile learning senam lantai dapat membantu belajar senam lantai kapan saja waktu mereka ingin belajar. Data tersebut ditunjukkan pada diagram gambar 3.

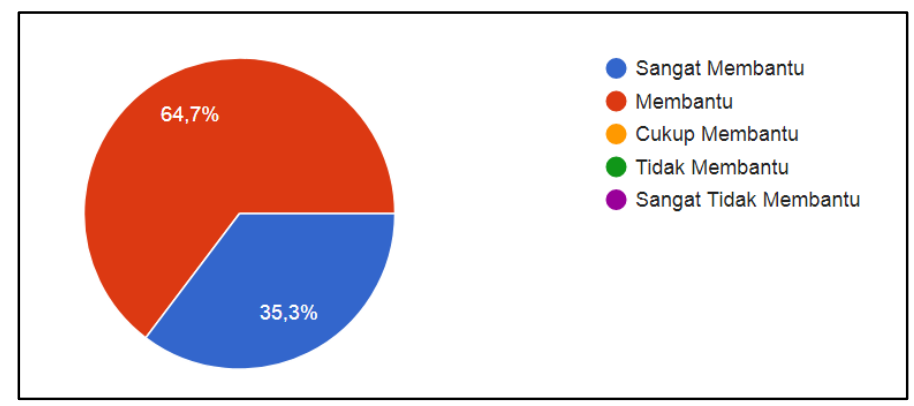

\section{Gambar 3. Persentase Mobile Learning Senam Lantai}

Data terkait kemudahan penggunaan media mobile learning senam lantai adalah sebagai berikut. Pertama, 29,4\% mahasiswa menyatakan bahwa media mobile learning senam lantai sangat mudah digunakan. Kedua, 64,7\% mahasiswa menyatakan bahwa media mobile learning senam lantai mudah digunakan. Ketiga, 5,9\% mahasiswa menyatakan bahwa media mobile learning senam lantai cukup mudah digunakan. Data tersebut digambarkan pada diagram gambar 4.

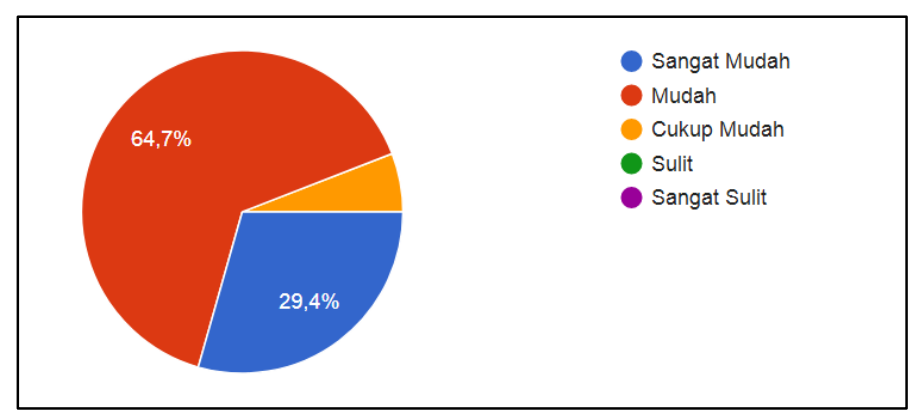

Gambar 4. Persentase Kemudahan Dalam Penggunaan Media Mobile Learning Senam Lantai 
Data terkait isi materi pada media mobile learning senam lantai dalam membantu mahasiswa belajar senam lantai adalah sebagai berikut. Pertama, 35,3\% mahasiswa menyatakan bahwa isi materi pada media mobile learning senam lantai sangat membantu mahasiswa dalam belajar senam lantai. Kedua, 52,9\% mahasiswa menyatakan bahwa isi materi pada media mobile learning senam lantai dapat membantu mahasiswa dalam belajar senam lantai. Ketiga, 11,8\% mahasiswa menyatakan bahwa isi materi pada media mobile learning senam lantai cukup membantu mahasiswa dalam belajar senam lantai. Untuk lebih jelasnya dapat dilihat pada diagram gambar 5.

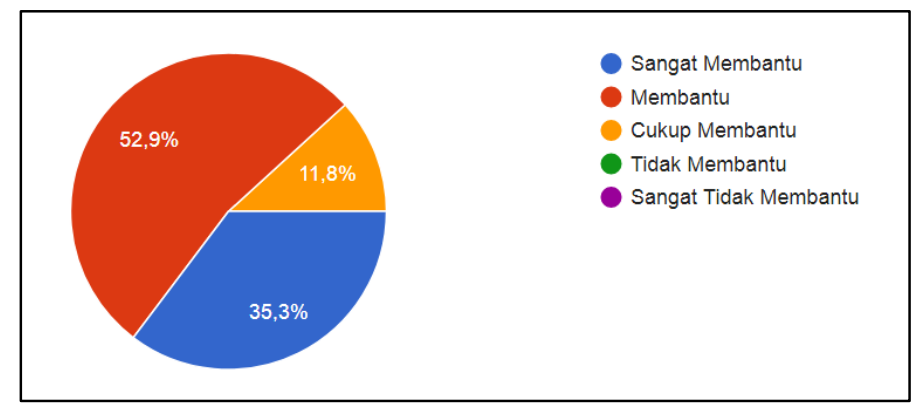

\section{Gambar 5. Persentase Manfaat Isi Materi Media Mobile Learning Senam Lantai}

Data terkait video pada media mobile learning senam lantai dalam membantu mahasiswa belajar senam lantai adalah sebagai berikut. Pertama, 29,4\% mahasiswa menyatakan bahwa video pada media mobile learning senam lantai sangat membantu mahasiswa untuk mempelajari senam lantai. Kedua, 52,9\% mahasiswa menyatakan bahwa video pada media mobile learning senam lantai dapat membantu mahasiswa untuk mempelajari senam lantai. Ketiga, 17,6\% mahasiswa menyatakan bahwa video pada media mobile learning senam lantai cukup membantu mahasiswa untuk mempelajari senam lantai. Data tersebut ditunjukkan pada diagram gambar 6.

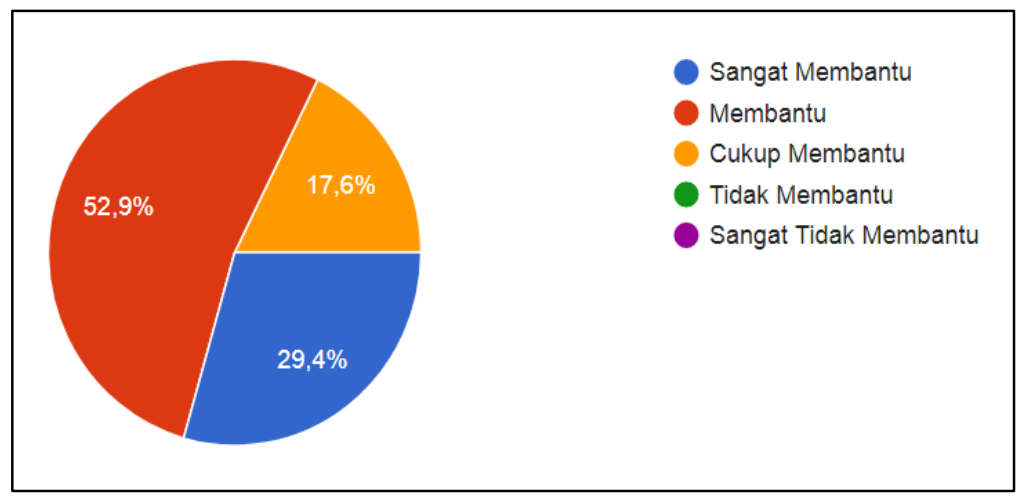

\section{Gambar 6. Persentase Manfaat Video pada Media Mobile Learning Senam Lantai}

Data tentang kemudahan memahami video pada media mobile learning senam lantai disajikan sebagai berikut. Pertama, 23,5\% mahasiswa menyatakan video pada media mobile learning senam lantai sangat mudah dipahami. Kedua, 70,6\% mahasiswa menyatakan video pada media mobile learning senam lantai dapat mudah dipahami. Ketiga, 5,9\% mahasiswa menyatakan video pada media mobile learning senam lantai cukup mudah dipahami. Data divisualisasikan pada diagram gambar 7 . 


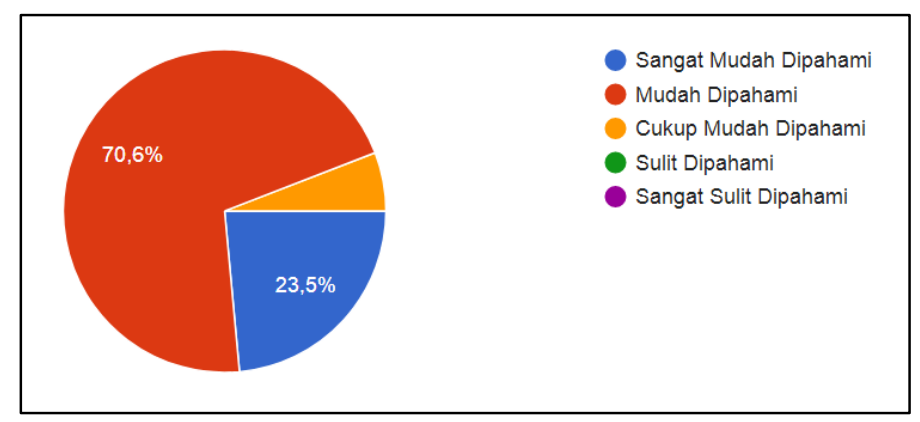

\section{Gambar 7. Persentase Tanggapan Mahasiswa tentang Kemudahan Memahami Video pada Media Mobile Learning}

Data terkait manfaat kuis pada media mobile learning senam lantai dapat mengukur pengetahuan mahasiswa tentang teknik keterampilan senam lantai adalah sebagai berikut. Sebesar 94,1\% mahasiswa menyatakan bahwa kuis pada media mobile learning senam lantai dapat mengukur pengetahuan mahasiswa tentang teknik keterampilan senam lantai. Sedangkan hanya sebesar 5,9\% mahasiswa menyatakan bahwa kuis pada media mobile learning senam lantai tidak dapat mengukur pengetahuan mahasiswa tentang teknik keterampilan senam lantai. Data dapat dilihat pada Gambar 8.

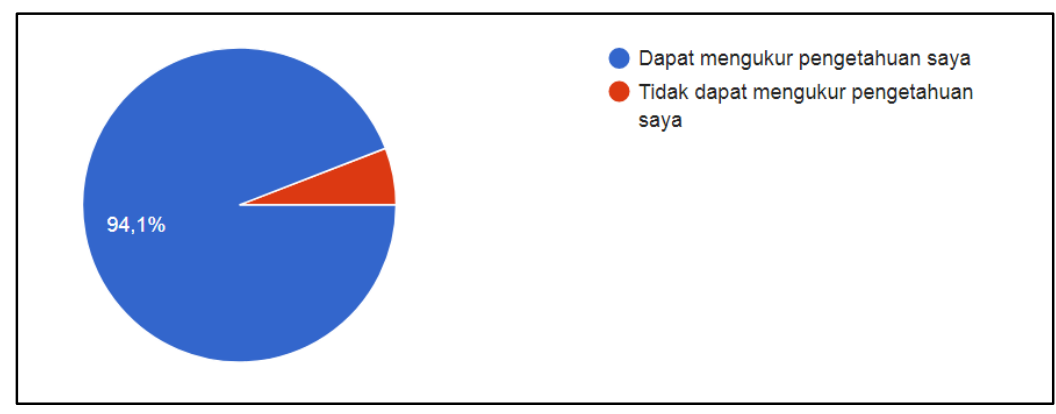

\section{Gambar 8. Persentase Terkait Manfaat Kuis Pada Media Mobile Learning Senam Lantai}

Kemudian diambil data juga tentang kemenarikan media pembelajaran yang digunakan pada mobile learning senam lantai. Data dipaparkan sebagai berikut. Sebanyak 17,6\% mahasiswa menyatakan bahwa media pembelajaran yang digunakan pada mobile learning senam lantai sangat menarik. Sebanyak 70,6\% mahasiswa menyatakan bahwa media pembelajaran yang digunakan pada mobile learning senam lantai menarik. Sebanyak 11,8\% mahasiswa menyatakan bahwa media pembelajaran yang digunakan pada mobile learning senam lantai cukup menarik. Untuk lebih jelasnya dapat dilihat pada diagram gambar 9.

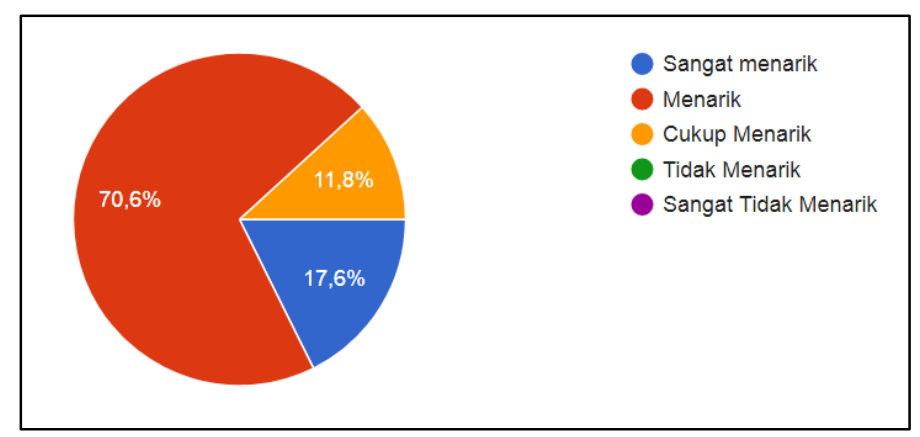

\section{Gambar 9. Persentase Kemenarikan Media Pembelajaran pada Mobile Learning Senam Lantai}

Peneliti juga mengambil tanggapan mahasiswa terkait efektivitas media pembelajaran yang digunakan pada mobile learning senam lantai dalam memberikan pengetahuan kepada mahasiswa tentang senam lantai. Tanggapan mahasiswa adalah sebagai berikut. Sebanyak 11,8\% mahasiswa menyatakan bahwa media pembelajaran yang digunakan pada mobile learning senam lantai sangat efektif dalam memberikan pengetahuan kepada mahasiswa tentang senam lantai. Sebanyak $76,5 \%$ 
mahasiswa menyatakan bahwa media pembelajaran yang digunakan pada mobile learning senam lantai efektif dalam memberikan pengetahuan kepada mahasiswa tentang senam lantai. Sebanyak $11,8 \%$ mahasiswa menyatakan bahwa media pembelajaran yang digunakan pada mobile learning senam lantai cukup efektif dalam memberikan pengetahuan kepada mahasiswa tentang senam lantai. Lebih jelasnya, data divisualisasikan dengan diagram pada gambar 10.

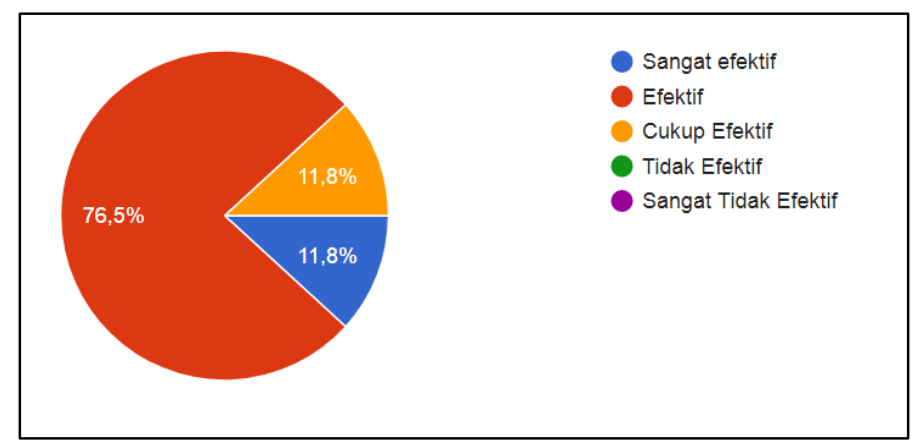

\section{Gambar 10. Persentase Tanggapan Mahasiswa Terkait Efektivitas Media Pembelajaran}

Data yang terakhir diambil adalah data tanggapan mahasiswa terkait kepraktisan media pembelajaran yang digunakan pada mobile learning senam lantai. Data yang diperoleh adalah sebagai berikut. Sebanyak 35,3\% mahasiswa menyatakan bahwa media pembelajaran yang digunakan pada mobile learning senam lantai sangat praktis digunakan. Sebanyak 52,9\% mahasiswa menyatakan bahwa media pembelajaran yang digunakan pada mobile learning senam lantai praktis digunakan. Sebanyak $11,8 \%$ mahasiswa menyatakan bahwa media pembelajaran yang digunakan pada mobile learning senam lantai cukup praktis digunakan. Gambaran data dapat dilihat pada diagram pada gambar 11.

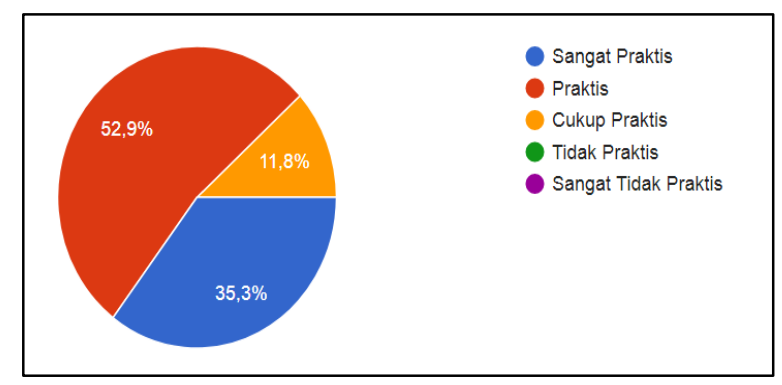

Gambar 11. Persentase Tanggapan Mahasiswa Terkait Kepraktisan Media Pembelajaran

\section{PEMBAHASAN}

Mobile learning merupakan pembelajaran yang dapat membantu ketika menghadapi permasalahan saat kekurangan waktu dan tempat. Karakter dari mobile learning ini dapat dilakukan dimana saja dan kapan saja waktunya. Mahasiswa yang memang merasa memerlukan lebih banyak waktu untuk memahami suatu materi pembelajaran, mahasiswa tersebut dapat menambah waktu belajar sesuai dengan kebutuhannya dengan melakukan mobile learning (Nordin, Embi, \& Yunus, 2010). Jadi, dapat disimpulkan bahwa mobile learning merupakan pembelajaran yang fleksibel, artinya dapat dimanfaatkan sesuai dengan kebutuhan mahasiswa (Wu, et al., 2012).

Mobile learning harus memaksimalkan media bahan ajar yang digunakan (Martin \& Ertzberger, 2013). Hal ini didasarkan pada alasan media yang digunakan sebagai pengganti sumber belajar dari seorang dosen. Artinya, media yang digunakan harus dapat menarik perhatian mahasiswa untuk belajar, materi jelas, mudah digunakan, mudah dipahami, mudah dipelajari, efektif, dan memiliki program evaluasi belajar (You \& Know, 2010).

Dari hasil data yang diperoleh menunjukkan bahwa media pembelajaran mobile learning senam lantai pada aspek penggunaan mendapat respons positif dari mahasiswa, sedangkan pada aspek efektivitas, media pembelajaran yang digunakan mendapat kategori efektif. Untuk aspek yang lainnya seperti kemenarikan, kejelasan materi, dan kemudahan mendapatkan respons yang positif dari semua mahasiswa. Kemudian pada aspek kemanfaatan kuis yang terdapat pada media pembelajaran dianggap bermanfaat oleh sebagian besar mahasiswa. 


\section{SIMPULAN}

Berdasarkan hasil analisis dan pembahasan di atas, maka mobile learning senam lantai mampu membantu mahasiswa dalam belajar di luar jam perkuliahan dimana saja tempatnya. Kesimpulan tersebut diambil berdasarkan pada penilaian mahasiswa terhadap media pembelajaran yang digunakan. Selanjutnya, mobile learning dapat dilaksanakan di kelas-kelas yang lainnya agar dapat membantu mahasiswa yang membutuhkan waktu lebih banyak dalam memahami isi dan materi-materi pembelajaran.

\section{DAFTAR RUJUKAN}

Allen, J. B. (2016). Social Motivation in Youth Sport. Journal of Sport and Exercise Psychology, 25(4), $551-567$. https://doi.org/10.1123/jsep.25.4.551

Eagleman, A. N. (2013). Acceptance, Motivations, and Usage of Social Media as a Marketing Communications Tool Amongst Employees of Sport National Governing Bodies. Sport Management Review, 16(4), 488-497. https://doi.org/10.1016/j.smr.2013.03.004

Gikas, J., \& Grant, M. M. (2013). Mobile Computing Devices in Higher Education: Student Perspectives on Learning with Cellphones, Smartphones \& Social Media. Internet and Higher Education, 19, 18-26. https://doi.org/10.1016/j.iheduc.2013.06.002

Gregersen, A. (2014). Cognition. In The Routledge Companion to Video Game Studies. https://doi.org/10.4324/9780203114261

Hasibuan, A. A., Syah, D., \& Marzuki, M. (2018). Manajemen Pendidikan Karakter di SMA. Tarbawi: Jurnal Keilmuan Manajemen Pendidikan, 4(2), 191-212. https://doi.org/10.32678/tarbawi.v4i02.1230

Holloszy, J. O., \& Coyle, E. F. (2017). Adaptations of Skeletal Muscle to Endurance Exercise and Their Metabolic Consequences. Journal of Applied Physiology, 831-838. https://doi.org/10.1152/jappl.1984.56.4.831

Ji, L. J., \& Yap, S. (2016). Culture and Cognition. Current Opinion in Psychology, 8, 105-111. https://doi.org/10.1016/j.copsyc.2015.10.004

Johannessen, J.-A., \& Johannessen, J. A. (2018). Knowledge Management and Organizational Learning. In Knowledge Management as a Strategic Asset. https://doi.org/10.1108/978-1-78769-659-420181005

Jones, W. M., \& Dexter, S. (2014). How Teachers Learn: The Roles of Formal, Informal, and Independent Learning. Educational Technology Research and Development. https://doi.org/10.1007/s11423-014-9337-6

Kelly, D. M., Gregson, W., Reilly, T., \& Drust, B. (2013). The Development of a Soccer-Specific Training Drill for Elite-Level Players. Journal of Strength and Conditioning Research, 27(4), 938-943. https://doi.org/10.1519/JSC.0b013e3182610b7d

Laursen, P. B. (2010). Training for Intense Exercise Performance: High-Intensity or High-Volume Training? Scandinavian Journal of Medicine and Science in Sports, 20(2), 1-10. https://doi.org/10.1111/j.1600-0838.2010.01184.x

Martin, F., \& Ertzberger, J. (2013). Here and Now Mobile Learning: An Experimental Study on the Use of Mobile Technology. Computers and Education, 68, 76-85. https://doi.org/10.1016/j.compedu.2013.04.021

Maruhashi, T., Kihara, Y., \& Higashi, Y. (2017). Exercise. In Therapeutic Angiogenesis. https://doi.org/10.1007/978-981-102744-4_15

Mayer, M. P. (2010). Gymnastics of Molecular Chaperones. Molecular Cell, 39(3), 321-331. https://doi.org/10.1016/j.molcel.2010.07.012

McKenzie, I. A., Ohayon, D., Li, H., De Faria, J. P., Emery, B., Tohyama, K., \& Richardson, W. D. (2014). Motor Skill Learning Requires Active Central Myelination. Science, 346(6207), 318-322. https://doi.org/10.1126/science.1254960

Nassar, L. (2017). Gymnastics. In Foot and Ankle Sports Orthopaedics. https://doi.org/10.1007/978-3-319-15735-1_55

Nordin, N., Embi, M. A., \& Yunus, M. M. (2010). Mobile learning framework for lifelong learning. Procedia - Social and Behavioral Sciences. https://doi.org/10.1016/j.sbspro.2010.10.019

Pelletier, L. G., Rocchi, M. A., Vallerand, R. J., Deci, E. L., \& Ryan, R. M. (2013). Validation of the revised sport motivation scale (SMS-II). Psychology of Sport and Exercise. https://doi.org/10.1016/j.psychsport.2012.12.002

Proctor, C., Tsukayama, E., Wood, A. M., Maltby, J., Eades, J. F., \& Linley, P. A. (2011). Strengths Gym: The Impact of a Character Strengths-Based Intervention on the Life Satisfaction and Well-Being of Adolescents. Journal of Positive Psychology, 6(5), 377-388. https://doi.org/10.1080/17439760.2011.594079

Ric, F. (2015). Social Cognition. In International Encyclopedia of the Social \& Behavioral Sciences: Second Edition. https://doi.org/10.1016/B978-0-08-097086-8.24044-0

Sands, W. A., McNeal, J. R., Penitente, G., Murray, S. R., Nassar, L., Jemni, M., ... Stone, M. H. (2016). Stretching the Spines of Gymnasts: A Review. Sports Medicine. https://doi.org/10.1007/s40279-015-0424-6

Sharples, M., \& Pea, R. (2014). Mobile learning. In The Cambridge Handbook of the Learning Sciences, Second Edition. https://doi.org/10.1017/CBO9781139519526.030

Sheth, H. (2016). Human Rights of Mentally Ill Clients. International Journal of Psychosocial Rehabilitation. 
Spriet, L. L. (2014). Exercise and Sport Performance with Low Doses of Caffeine. Sports Medicine, 44(2), $175-184$. https://doi.org/10.1007/s40279-014-0257-8

Sung, Y. T., Chang, K. E., \& Liu, T. C. (2016). The Effects of Integrating Mobile Devices with Teaching and Learning on Students' Learning Performance: A Meta-Analysis and Research Synthesis. Computers and Education, 94, $252-275$. https://doi.org/10.1016/j.compedu.2015.11.008

Wallhead, T. L., \& Ntoumanis, N. (2016). Effects of a Sport Education Intervention on Students' Motivational Responses in Physical Education. Journal of Teaching in Physical Education, 23, 4-18. https://doi.org/10.1123/jtpe.23.1.4

Wu, W. H., Jim Wu, Y. C., Chen, C. Y., Kao, H. Y., Lin, C. H., \& Huang, S. H. (2012). Review of Trends from Mobile Learning Studies: A Meta-Analysis. Computers and Education. https://doi.org/10.1016/j.compedu.2012.03.016

You, T., \& Know, S. (2010). Mobile APPS for Learning. Scenario. https://doi.org/10.1080/01972240701774774 